\title{
Mindful eating
}

\section{The Diet Fix: Why Diets Fail and How to Make Yours Work \\ Yoni Freedhoff MD \\ Random House Canada; 2014}

$\mathrm{T}$ he alarming green cover and promise-laden title are reminiscent of every other diet book I've read - and eventually discarded. But this is not a diet book. It is an evidence-based, common-sense guide to sustainable eating in our obesogenic culture. It won't stay on my book shelf long because I'll be lending it to friends.

CMAJ tried to find a physician expert to review the book, but as the author blurb proclaims, Freedhoff is one of the continent's most outspoken weight management critics: everyone knows him. Eventually, we mailed the book to an expert in Brazil and were perplexed when he said it wasn't his sort of book. I read the first chapter and realized it was in fact $m y$ sort of book: a book for serial dieters, no matter their waistline. It is for survivors of dieting sieges who have waged war with myriad armaments: Scarsdale, South Beach, WeightWatchers and so on. All of these diets achieved their aim - losing weight; none helped me achieve mine - keeping it off. Why? Because I felt deprived and soon reverted to mindless eating. I gained and felt like a loser. The Fix (also on Kindle) helped me realize that I have great will power (have you ever tried Scarsdale?), but deprivation sucks, and I'm only human. What I lacked were long-term solutions.

Behind every diet, whether embodied in programs, eating plans or books (there are 37000 of those), is the notion that to succeed, one has to suffer. And at the risk of being cynical, if these diets actually succeed, their business fails. And this is big business: a \$66-billion indus-

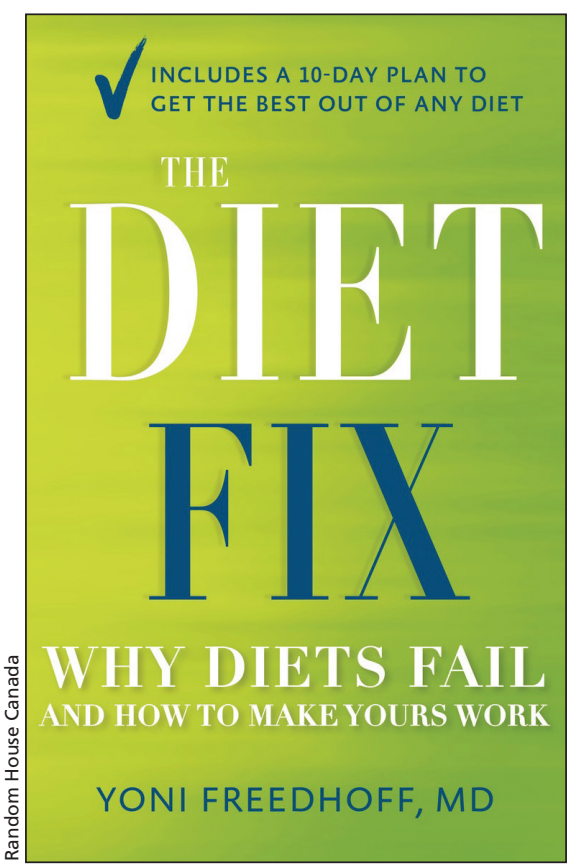

try, according to Freedhoff. His plan, launched with the 10-day Reset, is refreshingly different; it's all about being a permanent loser, about consuming "the smallest number of calories you need to enjoy your day." Not to discount other diets; if they work for you, continue, with a few tweaks that Freedhoff details, which may actually make them sustainable. Those tweaks include a few startling notions: never get hungry (eat protein every three hours); it's okay to indulge (eating is about more than food, it's also about celebrations and life); and you can't outrun your fork (weight is $70 \%-80 \%$ diet, $20 \%-30 \%$ exercise). The latter busts the myth that exercise is more important than food for weight loss. To lose one pound, you'd have to exercise 70-90 hours, according to Freedhoff's précis of the evidence. Physical fitness is important for lots of healthrelated reasons, but if you're out to shed excess weight, count your calories first.

It's hugely reassuring that Freedhoff shakes free from the snake-oil skull- duggery of most dieting gurus by using evidence to back up what he states. I checked the referencess: they pan out. And when the sample is small or the study animal-based, he says so.

A book review shouldn't reveal the plot. Suffice to say that the super hero is Captain Counting Calories. Keeping track is tedious, but there are brilliant online tools and, as Freedhoff points out, it only takes about five minutes a day. One analogy brought it home for me: dieting is like household budgeting. Most of us can't afford to go into a store and buy everything that catches our fancy: we check the price and choose what works best and what we need, within our price range. Ditto for food, but instead of the price, check the calories. If counting is what it takes to stay healthy, I'm willing to try it.

So what's not to like? Well, this is self-help, so it's inherently repetitive and bloated with rhetorical questions. It also assumes that the average person knows what protein looks like and, indeed, what a calorie actually represents (you'd be surprised). The recipes may be a tad ambitious for those who are new to the kitchen: I won't be making tortillas when I can buy healthy whole-wheat wraps. It also lacks some helpful hints I've gleaned from my dark dieting days - chew slowly and savour every bite, drink water, sit to eat, use a small plate, and so on - but you can't cram it all in one book.

Despite the hype of the screaming green cover, this is not your usual fare: it argues for a new way of thinking about food based on evidence, psychology and common sense. It's about eating smart, for life.

\section{Barbara Sibbald BJ}

Editor, News and Humanities CMAJ

CMAJ 2015. DOI:10.1503/cmaj.140949 